\title{
Tokyo Türk Maslahatgüzarının Değerlendirmeleriyle Mançukuo Devleti (1931-1933)
}

\author{
*Yonca ANZERLİOĞLU
}

\section{ÖZET}

Bu çalışmada 1931 yılında Mançurya'nın Japonlar tarafından işgal edilmesi ve kukla bir devlet olarak nitelendirilen Mançukuo Devleti'nin yaratılması sonrasında ortaya çıkan gelişmeler ve bu gelişmeler karşısında batılı devletlerin siyasetlerinin neler olduğu o dönemde Türkiye Cumhuriyeti'nin Tokyo Maslahatgüzarlığının hazırlamış olduğu konu ile ilgili rapora nasıl yansıdı̆̆ı, Türk dış politikası açısından Türk maslahatgüzarlı̆̆ının gelişmeleri nasıl değerlendirdiğ $i$ incelenmeye çalışılacaktır.

\section{ABSTRACT}

The invasion of Manchuria and establishment of a puppet state, Manchukuo, by the Japanese in 1931 creates a crisis both in this area and in the international arena at the eve of World War II. In this study it is tried to evaluate the effects of this invasion and the attitude of western countries according to the reports prepared by Turkish chargé d'affaires in Tokyo.

\section{GİRIŞ}

I. Dünya Savaşı sonrasında dünyada barışın sürekliliğinin sağlanması adına uluslararası işbirliği önem kazanmıştır. Ancak, barışı koruma çabalarına rağmen kısa süre içinde yaşanacak gelişmeler dünyanın yeni bir savaşa sahne olacağını göstermekteydi. Bu süreçte genellikle Avrupa'daki gelişmeler üzerine odaklanılsa da aslında uzak dogudan yükselen bir güç olarak Japonya da dünyanın savaşa sürüklenme sürecinde ciddi bir sorumluluğa sahiptir denilebilir.

\footnotetext{
• Hacettepe Üniversitesi Atatürk İlkeleri ve İnkılap Tarihi Enstitüsü Öğretim Üyesi.
} 
Bu bağlamda 1931 yılı büyük bir öneme sahiptir. Bu yıl içerisinde Japonya'nın Mançurya'ya saldırması aslında dünyayı yeni bir savaşa sürükleyen olaylar dizinin ilk siyasi buhranı olacaktır ${ }^{1}$.

Bu süreçte dış politikasında sorunları olmasına rağmen anti revizyonist safta yer alarak sorunlarını barışçı yollardan halletmeye çalışan genç Türkiye Cumhuriyeti, Avrupa'da yaşanan gelişmeleri yakından takip etmiş ve özellikle Balkanlarda Balkan Antantı'nın² oluşumunda (1933) etkin bir rol üstlenmiştir. Bu şekilde aktif barışçı dış politikası çerçevesinde batıya özel bir yer verirken aslında doğuda yaşanan gelişmeleri de göz ardı etmemiştir. Hatta dünya barışını tehdit eden tehlikenin bir başının da burada bulunduğu gerçeği dikkate alınarak Uzak Doğuda yaşanan gelişmeler de, batıdaki gelişmeler kadar dikkate alınmış ve bölgede bulunan elçilikler kanalıyla yaşanan gelişmeler yakından takip edilmiştir.

Bu çalışmada 1931 yılında Mançurya'nın Japonlar tarafından işgal edilmesi ve Mançukuo Devleti'nin yaratılması siyaseti, Cemiyet-i Akvam'dan çekildiği yıl olan 1933'de hangi gelişmelerin yaşandığ ve bu gelişmeler karşısında batılı devletlerin siyasetlerinin neler olduğu o dönemde Tokyo Türk Maslahatgüzarlığının hazırlamış olduğu konu ile ilgili rapora dayanılarak verilmeye çalışılacaktır ${ }^{3}$.

\section{Japon Genişleme Siyaseti ve Mançukuo Devleti'nin Kurulmast}

Bir adalar devleti olan Japonya, 19. yy. sonundan itibaren ciddi bir modernleşme süreci içine girmiştir. 1867 yılına kadar ülkede egemen olan feodal yapıya son verilirken, Meiji restorasyonu olarak anılan süreç içinde 1872'de Tokyo ile Yokohoma arasında ilk demiryolu inşa edilirken bir yıl sonra takvim ve hafta sistemi Avrupa örnek alınarak değiştirilmiş, zorunlu eğitim kararı alınmış ve çok kısa sürede ticaretten endüstriye geçiş gerçekleştirilirken ülkede yaşanan köyden kente göç ile endüstrideki iş gücü sağlamıştır. Bütün bu değişim ve modernleşme sürecinde toplum yapısındaki disiplin önemli bir yere sahip olmuştur. Zaman içersinde halkın idareye katılımı fikrinin ortaya çıkmasıyla başlayan süreç, 1890 yılına gelindiğinde yeni bir anayasa ilanı ve bir Avam kamarası ve asilzade meclisinden oluşan parlamenter bir sistem ile noktalanmıştır ${ }^{4}$. Gerçekte otoriter bir yapıya sahip

' Fahir Armaoğlu, 20. Yüzyıl Siyasi Tarihi, İstanbul, t.y., s.229, Locarno Antlaşmaları için ayrıca bkz. E.H. Carr. International Relations (1919-1939), London, 1993-97

2 Balkan Antantı ile ilgili olarak bkz. Armaoğlu, a.g.e., s.337-340; Mehmet GönlübolCem Sar, Olaylarla Türk Dış Politikası (1919-1973), Ankara 103-11

${ }^{3} 1931$ yılında Japonya'nın Mançurya'yı işgal etmesi ve bölgedeki Çin-Japon ve JaponRus Anlaşmazlıkları ile ilgili Türk Hariciye Vekaletinin hazırlamış olduğu rapor tarafımızdan daha önce incelenmiştir. Bkz. Yonca Anzerlioğlu "1931 Türk Hariciye Raporunda Çin-Japon Anlașmazlığı" CTAD, Güz 2006, ss.207-226.

${ }^{4}$ Eberhard, a.g.e., s.209. Japon modernleşmesi ile ilgili olarak detaylı bilgi için ayrıca bkz. W.G. Beasley, The Meiji Restoration, Stanford University Press, Stanford, 1972; Michio 
olan Japon idari sisteminde imparator tarafından tayin edilen Başbakanın kurduğu kabinede özellikle iki bakanlık oldukça etkili yere sahiptir. Hatta hükümetin devamı Milli Savunma ve Donanma Bakanlarına bağlıdır da denilebilir. 1882 yılında ordu ve donanma mensuplarının siyaset ile meşgul olamayacakları görevlerinin milli müdafaa olduğu kararı alınsa da, kısa zaman içinde milli müdafaa kavramı bütün hayatı kapsayan bir anlam kazanmıştır ${ }^{5}$.

Japonya'da siyasi gelişim bu yönde bir seyir takip ederken diğer taraftan gerçekleştirilmeye çalışılan endüstrileşme girişimi de ülke tarihinin seyrini etkileyen bir unsur olmuştur. Her şeyden önce belirtilmelidir ki, Japon endüstrisi için gereken temel maddeler ülke içinde mevcut olmadığından dışarıdan sağlanmaya çalışılmaktadır. Buna en çarpıcı örnek belki de neredeyse tüm demir ihtiyacının A.B.D'den satın alınmış olmasıdır. Diğer taraftan ülkede işçi ücretlerinin çok düşük olması Japon mallarının dünya fiyatları altında seyretmesine sebep olmaktaydı. Ayrıca, ülke nüfusu hızlı bir artış sergilemekteydi. Bu artış karşısında göç serbest bırakılmışsa da ülkeyi terk ederek Kore ve Formoza'ya giden Japon sayısının oldukça sınırlı kaldığ 1 da bilinen bir gerçektir ${ }^{6}$. İşte ülkedeki bu şartların etkisi ile Japonya bir genişleme siyaseti takip etmeye başlayacaktır.

Genişleme siyasetinin ilk hedefi ise Çin'in hamiliğini yaptığı Kore olmuştur. Japonya'nın Kore'ye yönelik takip ettiği siyaset iki ülkeyi savaşa sürüklemiş savaşın sonunda yenilgiye uğrayan Çin bu yenilginin bedeli olarak tazminatın dışında Formoza, Pescadores takım adaları, Lia-tung yarım adası ve orada bulunan Port Arthur limanını Japonya'ya bırakmak zorunda kalmıştır ${ }^{7}$. Tarihe Shimoneseki Antlaşması olarak geçen bu antlaşma ile Mançurya'nın güneyine yerleşen Japonya'nın bu galibiyeti bölge ile ilgileri olan Avrupalı devletleri de harekete geçirmiştir. Rusya, Mançurya ile ilgilenirken, Lia-tung yarım adasının karşısında yer alan Şantung Eyaleti ile Almanya ilgilenmekteydi. Bu arada Yang-tze vadisine yerleşmek için çaba sarf eden İngiltere bölgede Rusya'nın Yang-tze vadisine ulaşmasından çekinmekteydi. Hindiçini ile meşgul olan Fransa ise -ki Rusya ile ittifak antlaşması yapmıştır- Rusya'yı desteklemiştir. Aslında Rusya, Sibirya'dan Port Arthur'a demiryolu inşa etme iznini almışsa da özellikle Çin'in yenilgiye uğradığı Boksör Savaşı sonrası hızla bölgede yayılmaya başlayacaktır. Kore'nin kuzeyinde yer alan Vladivostok doğunun en önemli limanı iken Port Arhur da modern harp limanıdır. Bu şekilde Rusya'nın Mançurya ve Kore'yi işgal edeceği düşüncesiyle Japonya 1904 yılında Port

Umegaki, After the Restoration, The Begining of Japan's Modern State, New York, 1988; J.E. Thomas, Modern Japan, A social History since 1868, London, 1996.

${ }^{5}$ Eberhard, a.g.e., s. 212

${ }^{6}$ Eberhard, a.g.e., s. 212

7 Eberhard, a.g.e., 212; The Japonese Informal Empire in China, 1895-1937, ed. By Peter Duus, Ramon H. Myers, New Jersey, 1989, s.xiii 
Arthur ve Kore'ye karşı harekete geçmiştir. Rusların yenilgiye uğradığı bu savaşın sonunda Port Arthur, Japonlara teslim olurken Kore üzerinden Mançurya'ya ilerleyen Japonlar Mançurya'nın merkezi Mukden'e ulaşmışlardır. A.B.D.'nin arabuluculugu ile iki ülke arasında 1905 yılında Portsmouth'da antlaşma imzalanmış, bu antlaşmaya göre de Ruslar Çin toprağı olan Mançurya'dan çekilmek, Port Arthur, Dairen limanları ile Sahalin adasının güneyini Japonlara bırakmak zorunda kalmıştır. Ayrıca, Çin'in hakları göz ardı edilerek Japonya'nın Kore üzerindeki hakları da tanınacaktır ${ }^{8}$.

1905 yılında Rusya'da ihtilal olurken, Uzak Doğuda Japonya büyük devletler arasına dahil olacaktır. Bu arada Asyalı devletler açısından kısa bir süre önce sömürge olma tehlikesi ile yüz yüze gelen Japonya şimdi önemli bir güç haline gelmiştir. Bu bağlamda, Çin için de önemli bir örnek haline gelen Japonya, Rusya karşısında elde ettiği bu başarısı sonrası genişleme siyasetine devam edecektir. Birinci Dünya Savaşı öncesinde diğer Avrupalı devletler gibi Çin'de nüfuz sahibi olmaya çalışan Japonya özellikle sahil ve deniz nakliyatı sektöründe Çin'de etkili olmuştur. I. Dünya Savaşı dönemine gelindiğinde ise İngiltere'nin müttefiki durumundaki Japonya gerek Pasifik Okyanusunda gerekse Hint Okyanusu ve Akdeniz'de deniz savaşlarına katılmıştır. Bu şekilde müttefik donanmalarını himaye görevi üstlenen Japonya'nın asıl hedefini ise Çin oluşturmuştur. Bu arada Japonya'nın Kore üzerindeki haklarının tanınmasını bir süre sonra Kore'nin tamamen ilhakı izleyecektir. Çin ile doğrudan bir sınıra sahip olan Japonya için stratejik önemi dışında Çin, Japonya'nın tam karşısında yer alması ile bağlantılı olarak sanayisi için uygun bir pazar iken yukarıda belirtildiği gibi, artan nüfusu için de kolay bir nüfuz sahası durumundadır. Başka bir ifadeyle Çin, Japonya'nın genişleme siyaseti içinde oldukça önemli bir yere sahiptir'. Bu çerçevede, I. Dünya Savaşı döneminde savaş ortamından istifade ederek Japonya, Çin'deki Alman sömürgelerine sahip çıkmış ve Çin'e meşhur 21 teklifi kabul ettirmiştir. Bu antlaşma Türk hariciyesinin tanımlamasıyla "Japon emperyalizminin en korkunç vesikasıdır"10.

Çin'deki Alman imtiyazının Japonlara devrini sağlayan antlaşmaya göre Çin hükümeti siyasi ve askeri müşavirlerini Japonlardan seçeceğini, güney Mançurya'da, merkez ve kuzey Moğolistan'da Japonlara serbest ticaret, seyahat ve emlak edinme hakkı vereceğini, asgari ihtiyaçlarının \%50'sini Japonya'dan satın almayı ve Japonların Çin'de serbestçe dini propaganda yapmasını vs. kabul etmek zorunda kalmıştır. Daha sonra ise 1916 yılında Yüan S. Kai’nin ölümüyle Çin'in iç düzeni iyice karışmıştır. Bu durumu

${ }^{8}$ Eberhard, a.g.e., s. 212; William Fitch Morton, Tanaka Giichi and Japan's China Policy, New York, 1980, s. 14-19,

${ }^{9}$ The Japonese Informal, s.xiii; Anzerlioğlu, a.g.m. , s.215.

${ }^{10}$ Morton, a.g.e., s, 24. Anzerlioğlu, a.g.m., s.215. 
fırsat bilen Japonya, Rusya ile yaptığı bir anlaşma ile İç Moğolistan'da konsolosluklar açmıştır. Bu arada ABD savaşa girmiştir ve savaş ortamında Japonya'nın Çin üzerinde iddia ettiği hakları tanımayı tercih edecektir. 1917 yılında Japonya Shantung yarımadası için İngiltere, Fransa, İtalya ve Rusya ile anlaşacak ve Almanlara savaş ilan edecektir. Savaşın sonunda Almanya'ya imzalatılan Versailes Antlaşması görüşmelerinde Çin, Şantung yarımadasındaki eski Alman topraklarının kendisine iadesini istediyse de bu kabul edilmeyecektir. Bunun sonucunda Çin, Versailles Antlaşması yerine Almanlarla ayrı bir antlaşma imzalamak durumunda kalacaktır. Bu arada eski Alman takım adaları da Japonya'nın mandaterliğine verilecektir. Şunu da belirtmek gerekir ki, Japonya 1915 yılında Rusya'daki ihtilali de bir firsat olarak değerlendirip doğu Sibirya'ya asker göndermişse de Sovyet rejiminin kurulmasıyla askerlerini geri çekmek durumunda kalmıştır. 1922 yılına gelindiğinde ise Washington Deniz silahsızlanması konferansında özellikle Çin'e yönelik takip edilecek siyasetin belirlenmesi amacıyla yapılan görüşmelerin sonunda Amerika ve İngiltere'nin baskıları sonucu Japonya'nın 1915 yılında Çin'e kabul ettirdiği 21 tekliften oluşan antlaşma sona erdirilmiş ve onun yerine Çin'in egemenlik haklarının tanındığı ve bu bałlamda Japonya'nın istemeyerek imzalamak zorunda kaldığı Dokuz Devlet Pasifik Antlaşmas ${ }^{11}$ yürürlüğe girmiştir.

$\mathrm{Bu}$ anlaşmanın Japon iç siyasetinde değişikliğe sebep olduğu ve ülkenin siyasetinde belirleyici bir etkisi olan ve Japonya'nın emperyalist bir siyaset takip etmesi gerektiğini savunan askeri kesimi memnun etmemiştir. Ancak, iktidardaki liberal eğilimli Minseito Partisi Çin' e yönelik daha 1 lımlı bir siyaset uygulanması yönünde karar almıştır ${ }^{12}$. Ancak bu 1 lımlı siyaset ancak 5 yıl sürdürülebilmiştir. 1927 yılına gelindiğinde liberal hükümetin düşmesi ile askeri çevreler tarafından desteklenen Tanaka Giichi yeni hükümeti kurmuş ve başbakan Tanaka'nın imparatora sunduğu bir memorandum bundan sonra Japonya'nın izleyeceği yayılmacı siyasetin hedeflerine açıklık getirmiştir. Uzak Doğu'da Japonya'nın varlığının kurulabilmesi için Çin birinci derecede önem arz ederken Çin'in ele geçirilmesinden önce Mançurya ve Moğolistan'ın kontrol altına alınmasının gerektiği üzerinde durulan bu memorandum, her ne kadar 1929 da Tanaka, baskılar sonucu iktidardan çekilip yerine liberal parti yeniden iktidara gelse de, Japon siyasetinde önemli bir yere sahip olacaktır. Tanaka'nın en önemli destekçisi konumundaki askeri kesim özellikle de 1929 yılında dünyada ekonomik bunalımın baş gösterdiği dönemde bunu bir fırsat olarak değerlendirerek Japonya'nın Çin üzerindeki hakimiyetinin sağlanması için

${ }^{11}$ Yılmaz Altuğ, Çin Sorunu, İstanbul, 1995, s.53;.Carr, a.g.e., ss.20-22.

${ }^{12}$ Anzerlioglu, a.g.m., s. 215. 
öncelikle ele geçirilmesi gerektiğine inanılan Mançurya ve Moğolistan'a yönelik siyasetlerini uygulamaya koyacaklardır ${ }^{13}$.

Aslında Japonya'nın Mançurya'ya yönelik siyaseti 1905 yılından itibaren bir düzene konulmuştu denilebilir. Rusların ağır bir yenilgi sonrası bölgeyi terk etmelerinin ardından Japonya bölgeye yerleştikten hemen sonra ciddi bir ekonomik faaliyete başlamıştır. Bu bağlamda geniş bir demiryolu şirketi kurmayı planlamış ve büyük bir yatırımla Güney Mançurya Demiryolu Şirketinin oluşumu sağlanarak Japon emperyalist siyasetinin Mançurya topraklarında tesisinde önemli bir adım atılmıştır. Kurulan bu şirketin ilgi sahası sadece demiryolu ile de sınırlı kalmamıştır. Mançurya'nın maden ve orman işletmelerinden bazıları da bu şirketin işletmeciliğine verilirken, önde gelen şehirlerde iyi donanımlı hastaneler kurmak, Çinli tıp öğrencilerini okutmak ve Hıristiyan Japonlara kiliseler açmak gibi sosyal faaliyetlerde de bulunmaktaydı. 1929 yılına gelindiğinde Güney Mançurya Demiryolu Şirketi Dairen limanı ile Cha'ang-ch'un arasındaki 70 kadar yerleşim birimi ile Mukden ve Antung arasındaki 26 yerleşim birimini birbirine bağlamış ve demiryolu hattı boyunca şehirleşme oranı önemli biçimde artış göstermiştir. Kısacası, 1930'lu yıllara kadar Japonya, adı geçen demiryolu şirketinin de faaliyetleri ile Mançurya üzerinde, tıpkı Avrupalı devletlerin Çin üzerinde açık kapı politikası sayesinde oluşturdukları gibi, gayri resmi bir idare kurmayı başarmıștır. 1930'da Güney Mançurya'nın ihracatının \% 64'ü Japonya'ya giderken ithalatının \% 62'si Dairen kanalıyla Japonya'dan gelmekteydi. Ayrıca Japon endüstrisi için gereken kimyasal maddeler, metal ve metal ürünleri de bu bölgeden temin edilmekteydi ${ }^{14}$.

Her ne kadar Japonya güney Mançurya'da etkili bir yere sahip olsa da 1920'lerden itibaren yükselen Çin milliyetçiliği olayların seyrini etkiyecektir. Çin gençliğinin Japon yayılmacılığı karşısındaki tavrı, güney Mançurya demiryolunun ve eğitim kurumlarının Çinlilere iadesi şeklinde belirirken sokaklardaki işçi ve ögrenci gösterileri Japonlar açısından durumun ciddiyetini göstermekteydi. Bu noktada o dönem Türk Hariciyesinin Uzak Doğu gelişmelerini takip ile hazırlamış olduğu raporlar incelendiğinde Japon işgaline karşı bağımsızlık mücadelesini yürüten Çinli gençlerin "kapitülasyonları her nevi ecnebi imtiyazatın lağvederek bila kaydu şart şerefli bir istiklal temin etmek hususunda Türkiye'nin misalini" sıklıkla dile getirdiklerine vurgu yapıldıø̆ ${ }_{1}$ görülecektir. Bunun dışında Çin Hükümetin Japonya'nın idaresindeki güney Mançurya demiryolu ile rekabet edebilecek bir demiryolu inşasına, deniz ticaretinde önemli bir konumdaki

\footnotetext{
${ }^{13}$ Armaoğlu, a.g.c., s 233.

${ }^{14}$ Ramon H. Myers, "Japanese Imperialism in Manchuria: The South Manchuria Railway Company, 1906-1933" in Japanese Informal Empire in Chinal895-1937, ed. Peter Duus and Ramon H. Myers , New Jersey, 1989, s.116-127.
} 
Dairen limanına alternatif olabilecek Hulutav limanının ihyasına başlamak için teşebbüse geçmiştir ${ }^{15}$.

Ancak, Çin hükümeti bu tür girişimlerde bulunsa da yukarıda değinildiği gibi 1931 yılına gelindiğinde Japon askeri yetkilileri harekete geçmek için daha fazla bekleme taraftarı değildi ve Mukden hükümeti ile yaşanan çeşitli olay ve çatışmalar sonucunda 18 Eylül günü Mukden'in istasyonlarından birisinde patlayan bir bomba kıvılcımın ateşlenmesini sağladı ve Japonlar 1932 yılı Mart ayına kadar bütün Mançurya'yı işgal etti ${ }^{16}$.

Japonya'nın bu şekilde bir işgale kalkıştığı günlerde Çin'in müracaatı ile olaya dahil olan Cemiyet-i Akvam mesele ile ilgilenmeye başlamıştır. Ayrıca, Japon ordusunun Mançurya'da ilerlemesi karşısında ABD Dış İşleri Bakanı Stimson, İngiltere, Fransa ve İtalya büyükelçileri ile görüşerek 7 Ocak 1932 'de tarihe Stimson Doktrini olarak geçen bir açıklama yaparak Japonya'nın 1928 Paris Paktına aykırı davrandığını ve de facto ortaya çıkacak hiçbir oluşumun kabullenilmeyeceğini açıklamıştır. Bu arada Cemiyet-i Akvam 10 Aralık 1931'de Uzak Doğu'da yaşanan bu meselenin çözümü için Lytton komisyonu olarak anılacak bir inceleme komisyonu kurulmasına karar vermiştir. Diğer taraftan ise Japonya Başbakanı ve dış işleri bakanı ardı ardına yaptıkları açıklamalarda Japonya'nın Mançurya'dan ve Çin'den toprak talebinin olmadığını, buna karşılık Çin'in, Japonya'nın haklarını çiğnediğine ve bu bağlamda yaptıklarının sadece anlaşmalardan doğan, kazanılmış haklarını korumak olduğuna dikkat çekmişlerdir ${ }^{17^{7}}$.

Her ne kadar bu yönde açıklamalar yapılasa da Mançurya'daki Japon ilerleyişi devam edecektir. Bu durum karşısında Çin'in Japon mallarını boykot kararı alması Japonya'nın Çin'e gerçekleştirdiği ihracatında ciddi bir düşüşe sebep olmuştur. İki ülke ilişkilerinde var olan gerilim özellikle bu dönemde Şangay'daki Japonlar ve Çinli tüccarlar arasında artacak ve silahlı çatışmalar karşısında Çin, Cemiyet-i Akvam'dan Şangay olayının da incelenmesini isteyecektir. Bunun üzerine oluşturulan komisyonun hazırladığ $\breve{1}_{1}$ rapora dayanarak Cemiyet, Japonya'nın 1922'de imzalanan dokuz devlet anlaşması ve yine Cemiyet Misakının 10. maddesini ve Kellog Paktını ihlal ettiģini belirtilecektir. Cemiyetin mesele ile ilgili görüşmeleri devam ederken Japonya 26 Ocak tarihinde ateşkes ilan etse de Şangay meselesinde Cenevre'de alınan karar Japonlar tarafından hoş karşılanmayacaktır. Cemiyet, Japonya'yı haksız bulmuş ve Stimson Doktrinini benimsedigini ve mesele ile ilgilenmek üzere on dokuz üyeden oluşan bir komite oluşturulduğunu açıklamıştır. Sonuçta, Mançurya meselesi

\footnotetext{
${ }^{15}$ Anzerlioğlu, a.g.m., s. 216.

${ }^{16}$ Ian Nish, Japan's Struggle with Internationalism, Japan. China and The League of Nations, 1931-1933, London, 1992, ss.23-34.

${ }^{17}$ Takeuchi, a.g.e., s,376-373.
} 
ile beraber Şangay olayı iki ülkenin devam eden mücadelesinde 5 Mayıs 1932 'de bir anlaşma ile noktalanacaktır ${ }^{18}$.

Bu arada Mançurya'nın işgali sonrası Japon yanlısı Mançuryalı liderlerin katılımıla düzenlenen bir kongre ile 1 Mart 1932 tarihinde Mançurya topraklarında Mançukuo adıyla yeni bir devlet kurulduğu ilan edilmiştir. Yeni kurulan devletin başına 1911 yılında tahttan indirilen Mançu imparatoru Pu-Yi getirilmiştir. Ayrıca kurulan bu yeni devletin sınırlarına Japonların henüz işgal etmediği Çin'e ait Jehol eyaletinin de dahil edildiği açıklanmıştır. Özellikle askerlerin girişimiyle gerçekleşen bu işgal olayı karşısında Japon hükümetinin aldığı tavır da oldukça dikkat çekicidir. Seçimde büyük bir galibiyetle iş başına gelen ve askeri kesimle görüş ayrılığı içinde bulunan Inukai kabinesi, Cenevre'nin tavrı ile bağlantılı olarak, batılı devletlerle sorun yașamak istememektedir ve yeni kurulan bu devleti ancak bir emri vaki olarak değerlendirecektir ${ }^{19}$. Ancak yeni kurulan Mançukuo devletinin hemen tanınmaması olayı ülke içindeki siyasilerle askeri kesim arasında ciddi bir gerilim yaratırken, 15 Mayıs 1932 tarihinde Başbakan İnukai, bir grup subay tarafından öldürülmüştür. Bu durum 1lımlı siyaset takip etme taraftarı olanlar açısından ciddi bir uyarı olarak algılanacaktır $^{20}$. Bundan sonra ise hükümet düşmüş ve yerine yayılmacı siyaset yanlısı sivil ve askerlerden oluşan yeni bir hükümet kurulmuştur. Sonuçta, 3 Haziran 1932'de de Mançukuo Devleti Japonya tarafından resmen tanınmıştır.

Kurulan yeni Japon hükümeti ile Mançukuo hükümeti arasında ise 15 Eylül 1932 tarihinde yeni başkent olarak belirlenen Hsinking (Changchun)'da bir protokol imzalanmıştır. Bu protokole göre Mançukuo halkının serbest iradesiyle bağımsız bir devlet olarak varlığını Japonya tanırken Mançukuo da Japonya'nın Mançukuo topraklarındaki hukukuna riayet etmeyi kabul etmiştir. Bunun dışında dışarıdan gelebilecek her tehdit karşısında ortak savunma kararı alınmıs ve bu bağlamda, gerekli olan Japon askeri kuvvetinin Mançukuo'da kalmasına karar verilmiştir ${ }^{21}$.

Mançukuo'nun, gelişmeleri bir emri vaki olarak adlandıran Japonya tarafından resmen tanınması sonrasında yeni ülkede siyasi ve ekonomik yapılanmanın bir an önce gerçekleştirilmesi için çalışmalara hız verilmiştir. Fakat, her ne kadar siyasi çevrede tanınmış bir Mançukuo varsa da ülkenin kuruluşunda ve yapılandırılmasında askeriye birinci derecede rol oynamıştır. Hatta yeni devletin doğrudan doğruya Japon ordusunun

\footnotetext{
${ }^{18}$ Takeuchi, a.g.e., s.373-379.

${ }^{19}$ Nish, a.g.e., s.88.

${ }^{20}$ Takeuchi, a.g.e., s.382; Eberhard, a.g.e.,s. 225.

${ }^{21}$ Türkiye Cumhuriyeti'nin Hariciye Vekaleti bünyesindeki 2 ve 3 numaralı matbuat servisinin raporunda bu protokolün detayları bulunmaktadır. Bkz. Başbakanlık Cumhuriyet Arşivi, 03010220484 2, s.2,7.
} 
denetiminde olduğu dahi açıkça söylenebilir. Ayrıca, devletin başındaki kişi her ne kadar imparator Pu-Yi ise de Japonya'nın Mançurya'daki Kwantung olarak adlandırılan ordusunun başındaki komutan ülkenin gerçek idarecisidir ve başka bir ifade ile Mançukuo, Kwantug Ordusunun kurduğu bir devlettir ${ }^{22}$.

\subsubsection{Tarihli Tokyo Türk Maslahatgüzarlığı Raporunda} Mançukuo Devleti

1923 yılında kurulan Türkiye Cumhuriyeti, dış politikasında ilke olarak barışı hedefleyen anti revizyonist bir devlettir. Bu gerçeklerden hareketle dünyada yaşanan gelişmeleri yakından takip etmeye büyük önem vermiştir. Bu bağlamda, 1922 yılında barışı koruma adına imza edilen Kellog Paktına üyeliği çerçevesinde Uzak Doğuda yaşanan gelişmeleri bölge ülkelerinde bulunan elçilik ve konsoloslukları kanalıyla yakından takip etmiş ve bizzat kendi girişimleriyle hem Japonya'ya hem de Çin'e aralarındaki meseleyi barışçı yollardan halletmeleri konusunda çağrıda bulunmuştur. Olayları takip esnasında elçilikler ve maslahatgüzarlıklar tarafından hazırlanan raporlardan anlaşıldığına göre Milletler Cemiyetinin takındığı tavır ve etkisiz kalışı genç Türkiye Cumhuriyeti'nin Hariciye vekaleti yetkililerini cemiyetin fonksiyonu konusunda eleştirel yorumlara sevk ederken ve dünyanın genel durumu ile ilgili olarak "cihan sulhunun geçirmekte olduğu tehlikenin bir başı da bu noktadadır" yorumuyla bir savaşın yaklaşmakta olduğuna dikkat çekilmektedir.Yine 1931 yılı sonu itibariyle Japonya'nın Mançurya'daki işgali ile meselenin son bulmadığ ${ }_{1}$ ve hatta yeni başladı̆̆ına inanılmakta, bu çerçevede bölgede yaşanacak gelişmelerin Türk Hariciyesi tarafından büyük bir dikkatle takip edileceğine vurgu yapıldığı görülmektedir ${ }^{23}$.

$\mathrm{Bu}$ bağlamda, Mançurya topraklarının Japonlar tarafından işgal edilmesi ve sonrasında sözde bağımsız ancak gerçekte bir Japon kukla devleti kurulması sürecinde yaşanan gelişmeleri batı dünyası kaygı ile takip ederken ve Cemiyet-i Akvam'ın bu konudaki girişimleri genelde komisyonlar kurarak bölgede incelemeler yapmak ve uzun süre tartışmanın ötesinde bir yere varamadığı dönemde Türkiye Cumhuriyeti kendi başvurusu ile değil fakat Cemiyetin 6 Temmuz 1932'de daveti üzerine Cemiyet-i Akvam'a üye olacaktır. Cemiyetin genel kuruluna üyelik sonrası Konseye üyelik için iki yıl (1934) beklemek durumunda kalan Türkiye Uzak Doğuda yaşananları artık bir cemiyet üyesi olarak takip edecektir.

2 Nakagane Katsuji, "Manchukuo and Economic Development", in The Japonese Informal Empire, ed.by Peter Duus, Ramon H. Myers,et.al. New Jersey, 1989, ss. 133-165. Kwantung, güney Mançurya'da Japonya'nın kontrolü altındaki bir yer adı olup bu bölgenin savunması için 1906 'da oluşturulan ordunun adıdır.

${ }^{23}$ Konu ile ilgili detaylı bilgi için bkz. Anzerlioğlu, a.g.m., s.224. 
Cemiyet-i Akvam'a yeni üye olan Türkiye Cumhuriyeti'nin Japonya'nın Uzak Doğuda takip ettiği siyasete yönelik en önemli kaynağını Tokyo'daki Türk Maslahatgüzarlığı oluşturmuştur. Nitekim, Maslahatgüzarlığın hazırlamış olduğu konu ile ilgili rapor Hariciye Vekaleti tarafından Başvekalete sunulan Uzak şark ahvaline dair hazırlanan yedi numarall siyasi istihbarat dahilindeki 22.02.1933 tarihli ve 695/27numarada kayıtlıdır ${ }^{24}$. Adı geçen bu raporda Mançukuo Devletinin kurulmasından bir yıl sonrasına kadar geçen süre zarfında yaşanan gelişmeleri takip etmek mümkündür.

"Mançuri işinin dönüm yerinde bulunulduğu bir sirada son haberleri de katarak vaziyetin baştan aşağı gözden geçirilmesi faideli görülmüşü̈r” cümlesinin devamında Maslahatgüzar, Mançukuo Devletinin yaratılmasını Mançurya meselesinin ilk adımı, Jehol eyaleti ile iç Moğolistan'ın da Mançukuo'ya dahil edilmesini ikinci adımı ve sonuçta yeni kurulan devletin resmen tanıttırılmasını da üçüncü ve son adımı olarak değerlendirerek raporuna giriş yapmaktadır.

Daha sonra Mançukuo'nun kurulması ve yukarıda adı geçen yerlerin de bu yeni devlet sınırlarına dahil edilmesi ile ilgili olarak Japonya'daki durumun değerlendirilmeye başlandığı raporda Mançukuo'nun bağımsızlığının tüm dünya tarafından tanınması karşılığında ülkede var olan ılımlı Japonların bu iki yerden vazgeçmeye hazır olmalarına karşın çoğunluğun bu şekilde düşünmeyip Jehol ve iç Moğolistan olmadan kurulacak ve bağımsızlığı tanınacak bir Mançukuo'nun bir şey ifade etmeyeceğini savundukları beyan edilmektedir. Bundan sonra ise Mançurya'nın neden Japonya için bu kadar önemli olduğuna açıklık getirilmeye çalışılmakta ve ülke savunmasında gerekli olan önemli maddelerin Mançurya'da bulunduğuna değinilmekte bunun da ötesinde eğer tanınırsa Mançukuo'nun Japonya'ya başka açılardan da faydaları olacağına vurgu yapılmaktadır. Japon desteği ile hareket edebilen bir Mançukuo'da bir kara ve deniz kuvveti bulundurma hakkı er geç tanınacağına göre bu durum dünyada silahları azaltma kararlarına rağmen Japonya'ya bu bölgedeki iki rakibi olan Rusya ve Amerika karşısında kendi idaresi altında ucuz bir ordu ve donanmaya sahip olma imkanı sunacaktır. Bu durum Japonya'nın savunma siyaseti açısından olumlu bir katkı olarak değerlendirilebilirse de, Japon yayılmacı siyasetinde hızla artan ülke nüfusunun iskanı sorunu ile bağlantılı olarak Türk Maslahatgüzarı Mançuri'nin işgalinin bu soruna bir çözüm getiremeyeceği kanaatindedir. Japonlar asayişi düzeltip iktisadi

${ }^{24}$ B.C.A. 030.10.257.727.5; Tokyo Türk Maslahatgüzarlı̆̆ına ait konu ile ilgili rapor dışında yine 28 Kasım 1932 tarihinde Başvekalete sunulmak üzere hazırlanan Hariciye Vekaleti Beşinci Daire neşriyatı arasında yer alan "Şanghay ve Mançuri Hadiselerinin Son Safhaları" başlıklı detaylı bir rapor daha bulunmaktadır. Bu raporda da Japonya'nın Mançurya siyaseti ve Cemiyet-i Akvam ve tek tek batılı devletlerin tutumları irdelenmektedir. Bkz. B.C.A. 030102577289 . 
faaliyete geçmeye başladıktan sonra buraya az sayıda muhacir gelecektir. Çünkü Japonlar muhaceret işinde kabiliyetsizdirler. Dolayısıyla Mançurya toprakları artan Japon nüfusu karşısında etkili bir alternatif olamayacaktır. $\mathrm{Bu}$ mesele bir tarafa bırakılacak olursa ileride Mançurya, Japon sanayisine gereken temel maddeleri verse bile zamanla Japon sermayedarlarının el emeğinin ucuz olduğu Mançurya'da sanayi kurmalarının da güç olduğu raporun birinci bölümünün sonunda vurgulanan bir noktadır.

Raporun ikinci bölümünde Çin hükümetinin olaylar karşısındaki durumu ile ilgili olarak Milletler Cemiyeti'ne müracaat etmesinin dışında Tokyo'da bir haber olmadığına vurgu yapılarak başlanmakta ve bu konu ilgili olarak basında yer alan haberlerin de Japon kaynaklarına dayandığından doğruluguna güvenilemeyeceği belirtilmektedir. Ayrıca, Çin'in iç siyasetinin karmaşıklığından dolayı sağlıklı bir bilgi almak da mümkün değildir. Ancak yine de başka kaynaklar aracılığı ile Çin'in olaylar karşısındaki durumunun değerlendirildiği görülmektedir ${ }^{25}$.

$\mathrm{O}$ gün için Çin'deki iç karışıklıktan dolayı bölgelere ayrılmış bir yapıya sahip olan Çin, temelde iki büyük grup tarafından idare edilmektedir. Nankinliler ve Kantonlular. Bu iki gruptan milliyetçi bir siyaset takip eden Kantonlular bağımsızlık için son kuruşlarına ve son insanına kadar mücadele etme taraftarıdırlar ve sayıları az olmasına rağmen Çin ile ilgili meselelerde dikkate alınması gereken bir unsurdurlar. Nankinliler ise milli hissiyata sahip olsalar da onlar için ülkede milli kuvvet oluşturmadan önce dış yardıma ihtiyaç vardır. Kantonlulara göre ise bunun tam tersi söz konusudur, önce içeride milli kuvveti tesis sonra ise dış yardım alınabileceğine inanmaktadırlar. Türk maslahatgüzarına göre o an için Çin'in Mançurya'ya yönelik nasıl bir tavır takınacağı ülkede hangi grubun üstünlük sağlayacağına bağlıdır. Ancak Alman elçisinin verdiği bilgiye dayanarak yakın bir zamanda böyle bir gelişme beklenmemektedir. Dolayısıyla o an için Çin'in Mançurya siyasetini bu iki grubun savunduğu fikirlerin bileşkesi şeklinde değerlendirmek yanlış olmayacaktır.

Mançurya meselesini yakından takip eden bir diğer devlet olarak Rusya'nın nasıl bir siyaset takip ettiği de Türk Maslahatgüzarının üzerinde durduğu önemli bir noktadır. Japon etki sahasının kuzeye doğru ilerlemesine engel olamayan Rusya, rejim olarak Sovyet idaresini kabul eden Mogolistan'ı kurtarma yoluna gitmiştir. Buna karşın, Mançurya'da Japon yerleşimini kabul etmek zorunda kalmış, Japonya ile anlaşmak için konsoloslarını kabul ederek bir anlamda Mançukuo'yu fiilen tanıma noktasına gelmiştir. Ayrıca, Çin'de güçlü bir hükümet kurulması durumunda ya da Mançurya'da tam anlamıyla Japon nüfuzunun yerleşmesi karşısında Çin Şark demiryolunu satmayı planlamışsa da Japonlar bunu kabul

\footnotetext{
${ }^{25}$ B.C.A. $030.10 .257 .727 .5 .$, s.10-12.
} 
etmemişlerdir. Bu durum karşısında Amerika ile anlaşmanın yollarını da arayan Rusya'nın doğru bir hareket içinde olduğu yorumunu yapan Maslahatgüzar, böylelikle Rus-Amerikan ilişkilerinde bir yakınlık meydana geldiğinin de kesin olduğuna vurgu yapmaktadır. Bu yakınlaşma ile ayrıca Çin'e yakın davranan Amerika ile anlaşma sağlamasında Rusya'nın maddi ve manevi daha önemli menfaatlerinin olduğunu da belirttikten sonra Amerika'nın durum karşısındaki tutumuna değinen maslahatgüzara göre Amerika'nın temel politikasının da diğer sanayisi gelişmiş devletlerden farklı olmadığı ve sanayi ürünlerine pazar aramak ve bu pazarı muhafaza etmekten ibaret olduğunun altını çizmektedir.

Bu bağlamda, Birinci Dünya Savaşı sonrasında dünyanın bazı yerlerinin pazar olmaktan çıktığı ve o gün için yalnız Pasifik pazarının bu siyaseti tatmin eder konumda kalması ile birlikte Amerika'nın bu pazarın önemli bir kısmını Japonlara bırakması ve hatta geri kalan kısmında da Japon rekabetini kolaylaştıracağını düşünmek, özellikle Filipinlerin iktisadi nedenlerden dolayı ayrılmasını olumlu karşıladığ görünmemektedir. Ancak şu da bir gerçektir ki Amerika, Mançurya için her şeyi göze alan Japonlarla çarpışmaktan da çekinmektedir. Amerika'nın bu mesele karşısındaki tutumunun sadece cumhuriyetçilere ait olup demokratların bunu değiştirebileceğini düşünmek de, Amerikan hükümetlerinin aldığı kararlara bakıldığında pek doğru görünmemektedir.

Amerika'dan sonra bölge ile ilgilenen bir diğer önemli güç olan İngiltere'nin de bölgedeki gelişmeler karşısında takip ettiği siyaseti değerlendiren Türk maslahatgüzarına göre muhafazakâr İngiliz hükümeti 1905 de başlayan ve 1911 'de devam eden muahedelerle belirlenen siyasete devam etmeyi tercih etmektedir. Bu siyaset çerçevesinde; Japonya'nın sıkıştırılması karşısında Milletler Cemiyetini terk edeceği bunun da İngiltere için gerekli olan bu kurumu zayıflatabileceği, Japonya'nın Cemiyetin kararını kabul etmemesi durumunda İngiltere'nin üzerine ağır bir külfetin düşeceği, iktisadi ve mali ilişkinin kesilmesi durumunda ise İngiltere'nin Hindistan'daki iktisadi sıkıntısını artıracağına inanılırken, Rusya'nın uzak doğudaki varlığı karşısında da Japonya'nın hareketine olumlu yaklaşılsa da, şimdilik Amerika ile bir anlaşmazlık yaşamak istemeyecektir. Ayrıca, bu siyaset İngiltere'yi Amerika'nın baskısıyla Japonya ile olan ittifakını feshetmek durumunda bırakmıs ve Japonya'yı Amerika'ya tercih edemeyeceğinden dolayı da siyasetini tatbike imkan bulamamıştır. Bu durumda iki tarafı anlaştırmayı ve İşçi Partisinin kurduğu "Çin'e yardım siyasetini tutar gibi görünerek" İngiltere'de Çin'i destekleyenleri memnun etme yolunu tercih etmiştir ${ }^{26}$.

\footnotetext{
${ }^{26}$ B.C.A. 030.10 .257 .727 .5$, s.16.
} 
Bunun dışında Japonya nezdinde gerçekleştirdiği girişimlerle bu devleti Amerika'ya yaklaştırmaya çalışmış, Milletler Cemiyetine üye küçük devletlerin Japonya aleyhine tezahüratlarının önüne geçmeye çalışmıştır. Kısacası, bir Japon-Amerikan anlaşmazlığını engellemek için uğraşan İngiltere, Japonya'nın olumsuz yaklaşımı sonucu Amerika ve diğer devletleri Milletler Cemiyetinde "istedikleri kararl almakta serbest bırakmaya" mecbur olmuş ve yine alınacak kararın mümkün olduğunca yumuşak olması ve her şartta açık bir kapı kalması için çaba sarf ederek bir anlaşma çaresi bulunabileceği ümidini kesmemiştir ${ }^{27}$.

İngiltere kadar bölge ile yıllardan beri ilgili olan bir diğer devlet olarak Fransa'nın bölgedeki gelişmeler karşısında nasıl bir tavır sergilediği konusunda da bir değerlendirme yapan Türk Maslahatgüzarı, anılan devletin olaylara bölgedeki sömürgesi Hindi Çini ekseninde yaklaşarak, komünist propagandasına müsait bir yer olmasından dolayı, öncelikle bölgedeki Rus varlığı üzerine odaklandığına dikkat çekmektedir. Bu bağlamda, Milletler Cemiyeti'nin ılımlı karalarına bakarak İngiltere'den ayrılmamak ve Uzak Doğu'da, daha önce de belirtildiği gibi, Rusya'ya karşı Japonya'yı kazanmak gibi bir siyaset belirlemiştir. Bunun yanında müstemlekeci kimliği ile "Fransa'nın da sinai mahsullerin gönderileceği çok nüfuslu bir memleketi istilanın meşru şekil almasını istemesi tabii görülürr. Bununla beraber zamanın Uzak Şark'ta faal bir rol oynaması şüphelidir"28.

Diğer taraftan, Faşizmin faaliyetini göstermek hevesinde olan İtalya ise Uzak Doğu'ya yönelik olarak fazla önemli olmasa da yine de çıkarlarımı korumak adına bir siyaset belirlemiştir ve yine sömürgeci bir devlet sıfatı ile Japonya'nın girişimlerinin dünya siyasetinde kabulünü göstermek adına Japonya meselesi ile ilgilenmektedir.

$\mathrm{Bu}$ şekilde Uzak Doğu ile ilgilenen müstemlekeci kimliğine sahip devletlerin temel siyasetlerini izahtan sonra uluslararası barışı koruma adına savaş sonrası döneme imzasını atan Milletler Cemiyetinin Japon yayılmacı siyaseti karşısında o sıralarda aldığ ${ }_{1}$ ve alacağ ${ }_{1}$ kararların takip edilemediğinin altının çizildiği raporda Milletler Cemiyetine karşı Japonya'nın nasıl bir siyaset takip ettiğine yer verilerek devam edilmektedir.

Bu çerçevede Japonya'nın cemiyetten çıkma eğilimi göstermesi meselenin alacağ tavra ve bu tavrın Japon siyasileri üzerinde yapacağı etkiye bağlıdır. Ayrıca, Cemiyetin, İngiltere'nin siyasetine rağmen, bir karar vermesi Japonya'da Cemiyetten ayrılma fikri yönünde bir harekete sebep olmuştur. Bu açıdan bakıldıð̆ında Japon Harbiye Nezareti, Milletler Cemiyetinden çekilmek ile ilgili olarak basına bir açıklama yapmıştır. Japonya'nın, Mançurya'yı işgal

\footnotetext{
${ }^{7}$ B.C.A. $030.10257 .727 .5,17$

${ }^{28}$ B.C.A. 030.10.257.727.5, s.17.
} 
ettiği andan itibaren yalnız kaldığı ve Cemiyetten çekilmesi durumunda da bu yalnızlığın şiddetinin artmayacağına vurgu yapılarak, Cemiyetten çekilmesi ile birlikte Japonya'nın başta İtalya ve Sovyetler olmak üzere diğer devletlerle olan ilişkilerinin olumsuz yönde etkilenmeyeceğine değinilmektedir. Mançurya'nın işgali karşısında Cemiyetin alacặı iktisadi ablukanın küçük devletler tarafından değil fakat İngiltere, Amerika, Fransa ve İtalya gibi büyük devletler tarafından uygulanacăğ açıdan sıkıntıda olan bu ülkelerin Japonya ile bir savaşı göze alamayacaklarına vurgu yapıldı ğı görülmektedir. Bunun dışında güney denizinde Japonya'nın mandaterliğinde bulunan adalar ile ilgili olarak da Japonya'nın buraları bırakması durumunda Amerika'nın buraları kendi hakimiyetine almak istediğinin çok açık olduğu ancak, Japonya'nın Milletler Cemiyeti'nden çekilmesinin bu adaları bırakacağı anlamına gelmediğinin altının çizildiği belirtilmektedir.

Ülkede siyasetin belirlenmesinde önemli bir konuma sahip olan askeri kesimin bu açıklamaları arkasından Hariciye Nezaretinin de bir açıklama yaptığına değinilen raporda Japon Hariciyesinin Milletler Cemiyetinden çekilme kararı alındıktan ve bunun Cemiyete tebliğinden sonra iki yıl süreyle daha cemiyetin azası olmaya devam edeceği ve bu süre zarfında cemiyet meclisinin ve genel kurulun toplantılarına katılmayacağına ancak silahsızlanma konferansına katılacağına vurgu yaptığı belirtilmektedir. İki yıl sonunda silahsızlanma konferansından da Japonya'nın çekileceğinin belirtilmesi dışında Cemiyetten çekilmenin Güney Denizindeki mandaterliğini yaptığı adalardan çekilmesi anlamına gelmediğinin altı çizilirken yine bu bağlamda her ne kadar cemiyet üyesi olmasa da Japonya'nın kültürel faaliyet açısından Milletler Cemiyeti ile ilişkisinin devam ettirileceği belirtilmektedir ${ }^{29}$.

Japon Harbiye ve Hariciye Nezaretlerinin bu açıklamalarının yer verilmesinin ardından ülkedeki genel durumun bir değerlendirmesinin yapıldığı rapora göre Japonya'da küçük bir ekseriyet daimi üyelik, Pasifik adaları meselesi ve cemiyetten çekilmenin olumsuz olacağını düşünse de, çoğunluk, özellikle de askeriye çekilmeye kesinlikle taraftardır ve ülkedeki diğer karar mekanizmalarını da peşlerinden sürüklemektedir. Nitekim, yer verilen Hariciye ve Harbiye Nezaretlerinin açıklamalarının da bu görüşü desteklediği açıkça ortadadır.

Sonuç itibariyle, Tokyo'da Prens Saiyonji ve Askeri Şura'nın görüşmelerinin ardından Japonya'nın Milletler Cemiyetinden çekilmesine karar verilmiştir. Karar aşaması sonrasında bunun uygulanması için cemiyetin vereceği kararın nihai şeklinin verilmesi beklenmektedir.

\footnotetext{
${ }^{29}$ B.C.A. 030.10 .257 .727 .5 , s. 19.
} 
Milletler Cemiyetinin vereceği kararı bekleyen Tokyo'da cemiyetten çekilmeye karşı olan bir siyasi partinin de görüşlerine değinilen raporun son iki sayfasında Sahakai-Taishuto adındaki bu Sosyalist Partinin Cemiyetten çekilme kararı ile uluslararası yalnızlığa itilen Japonya'nın Mançurya siyaseti ile Milletler Cemiyeti Misakı, Dokuz Devlet Muahedesi ve Kellog Misakı'na aykırı davrandığına ve komşu devletlerle yakın ilişki kurulması ile bir milli diplomasinin oluşturulması gerektiği fikrini savunduğu ve bu bağlamda da Sovyetlerle saldırmazlık misakı imzalanabileceği ve Çin'le de birlikte çalışılması gerektiğine dair bir karar aldığına değinilmektedir.

Bundan sonra ise Türk maslahatgüzarı Japonya'nın Mançurya meselesini dilediği gibi halledebilmek için her şekilde hazır bulunduğuna vurgu yaparak, ne zaman olacağı belli olmamakla birlikte, eğer gereken tedbirler alınmasa, bir Pasifik Savaşı çıkacağının kaçınılmaz olduğu ve bu çerçevede bu tür bir savaşa başlangıç teşkil edecek olan Çin-Japon anlaşmazlığının dikkatle takip edildiğine vurgu yaparak raporuna son vermektedir.

Tokyo Türk Maslahatgüzarının Japonya'nın Cemiyet-i Akvam'dan çekilmesi kararını belirttiği yukarıda detaylarına yer verilen raporu tamamlayıcı mahiyette bazı bilgileri yine Türk Hariciyesi bünyesindeki matbuat servisinin 25 Şubat 1933 tarihinde Başvekalete sunulmak üzere hazırladığı raporlarda bulmak mümkündür.

Bu bağlamda, 8 Şubat 1933 yılında La Republique gazetesinde "Tokyo'da bütün firkaların iştirak ettiği bir içtimada Japonya'nın Milletler Cemiyeti'nden çekilmesi istendi" başlıklı Tokyo'dan Reuters Ajansına geçilen bir habere atfen beş bin üyenin hazır bulunduğu parti temsilcileri toplantısında Milletler Cemiyeti'nin yaptıkları hatalar ve Mançurya meselesi ile ilgili anlaşmalarda ciddi hareketlerde bulunmadı $\breve{g}_{1}$, bu konu ile ilgili olarak cemiyet misakının 15 . maddesinin 4. fıkrasını uygulayacağından, Lytton raporuna dayanarak Mançukuo Devletini ve Japonya'nın hayati çıkarlarını müdafaa hakkını tanımadı ı̆ından ve Çin'in Japonya'ya uyguladığı boykotu kabul ederek meselenin halli konusunda cemiyetin ruhu ile ters düştügünden ve Japon milletinin buna izin vermeyeceğinden dolayı meclisin Japonya'nın cemiyetten çekilmesine ve Cenevre'deki temsilciler heyetini geri çağırmaya karar verildiğine dikkat çekildiği görülmektedir. ${ }^{30}$

Bu şekilde Cemiyet-i Akvam'dan çekilme kararı alan Japonya, yaklaşık bir ay sonra 4 Mart'ta 1933 'de Mançukuo dışında adından bahsedilen Çin'in Jehol eyaletini de işgal edecektir ${ }^{31}$. Bu işgal ile uzun zamandan beri belirlemiş olduğu yayılmacı siyasetine devam eden Japonya, artık kendisinden beklenen performansı gösteremeyen Cemiyet-i Akvam ile olan

${ }^{30}$ B.C.A. B.C.A. 0301025772615 , s. 6 .

${ }^{31}$ Alvin D. Cox, "The Kwantung Army Dimension", in The Japanese Informal, s.414. 
ilişkilerini de sona erdirerek tam anlamıyla saldırgan bir siyaset takip edecektir.

Uzak Doğuda Japonya'nın bu tutumunun benzerinin Avrupa'da Hitler Almanyası ve Mussolini İtalyası tarafından sergilendiği bilinmektedir. Nitekim, Japonya'nın Cemiyet-i Akvam'dan çekilmesinden sonra Ekim 1933'de Almanya ve Aralık 1937'de İtalya da cemiyetle olan bağlantılarını sona erdirecektir. Buna bağlı olarak adı geçen bu ülkelerin belirledikleri revizyonist siyasetlerine hız vermeleri, bunun dışında Cemiyet-i Akvam'ın kendi üyesi olan revizyonist ülkelerin siyasetlerine karşı etkili bir tavır sergileyememesi ve Türk Maslahatgüzarının tabiriyle müstemlekeci kimliğine sahip batılı ülkelerin de özelde öncelikli olarak kendi çıkarları doğrultusunda tavır sergilemeleri ve sonuçta barışı koruma adına gerçekleştirilen tüm uluslararası girişimlerin başarısızlıkla sonuçlanması ile dünya yeni bir savaşın içine sürüklenmiştir. Bu ortamda, yukarıda vurgulandığı gibi Türkiye Cumhuriyeti olayların en başından itibaren anti revizyonist ve barış̧̧ı bir dış politika ile dünyada var olan statükonun korunması için çaba sarf edecek, gerek Balkanlarda ve Akdeniz'de gerekse Uzak Doğu'da yaşanan gelişmeler karşısında oldukça hassas bir yaklaşımla geleceğe yönelik gerçekçi çıkarsamalar yaparken ilerleyen yıllarda savaş dışı kalmayı başaran bir devlet olacaktır. Bu siyasetini yürütürken yönünü batıya çeviren bir devlet olsa da, sadece batıda yaşanan gelişmelere odaklanmayacak, dünya barışının geçirmekte olduğu buhranın bir başının da doğuda olduğu gerçeğine dayanarak doğuda yaşanan gelişmeleri de bölgedeki temsilcilikleri kanalıyla ve yerinde tespitlerle büyük bir önem vererek takip edecektir. 